University of Nebraska - Lincoln

DigitalCommons@University of Nebraska - Lincoln

2019

\title{
Role of Sea Surface Temperatures in Forcing Circulation Anomalies Driving U.S. Great Plains Pluvial Years
}

\author{
Paul X. Flanagan \\ University of Nebraska - Lincoln, pflanagan@unl.edu \\ Jeffrey B. Basara \\ University of Oklahoma \\ Jason C. Furtado \\ University of Oklahoma \\ Elinor R. Martin \\ University of Oklahoma \\ Xiangming Xiao \\ University of Oklahoma
}

Follow this and additional works at: https://digitalcommons.unl.edu/hprccpubs

Part of the Atmospheric Sciences Commons, Climate Commons, Environmental Indicators and Impact Assessment Commons, Environmental Monitoring Commons, Fresh Water Studies Commons, Hydrology Commons, Meteorology Commons, Natural Resources Management and Policy Commons, Sustainability Commons, and the Water Resource Management Commons

Flanagan, Paul X.; Basara, Jeffrey B.; Furtado, Jason C.; Martin, Elinor R.; and Xiao, Xiangming, "Role of Sea Surface Temperatures in Forcing Circulation Anomalies Driving U.S. Great Plains Pluvial Years" (2019). HPRCC Personnel Publications. 30.

https://digitalcommons.unl.edu/hprccpubs/30

This Article is brought to you for free and open access by the High Plains Regional Climate Center at DigitalCommons@University of Nebraska - Lincoln. It has been accepted for inclusion in HPRCC Personnel Publications by an authorized administrator of DigitalCommons@University of Nebraska - Lincoln. 


\title{
Role of Sea Surface Temperatures in Forcing Circulation Anomalies Driving U.S. Great Plains Pluvial Years
}

\author{
PAUL X. FLANAGAN \\ School of Meteorology, University of Oklahoma, Norman, Oklahoma, and High Plains Regional Climate Center, and \\ School of Natural Resources, University of Nebraska-Lincoln, Lincoln, Nebraska \\ JEFFREY B. BASARA \\ School of Meteorology, and School of Civil Engineering and Environmental Science, University of Oklahoma, \\ Norman, Oklahoma \\ JASON C. FURTADO AND ELINOR R. MARTIN \\ School of Meteorology, University of Oklahoma, and South Central Climate Adaptation Science Center, Norman, Oklahoma \\ XIANGMING XIAO \\ Department of Microbiology and Plant Biology, Center for Spatial Analysis, University of Oklahoma, Norman, Oklahoma
}

(Manuscript received 24 October 2018, in final form 19 July 2019)

\begin{abstract}
In the U.S. Great Plains (GP), diagnosing precipitation variability is key in developing an understanding of the present and future availability of water in the region. Building on previous work investigating U.S. GP pluvial years, this study uses ERA twentieth century (ERA-20C) reanalysis data to investigate key circulation anomalies driving GP precipitation anomalies during a subset of GP pluvial years (called in this paper Pattern pluvial years). With previous research showing links between tropical Pacific sea surface temperature (SST) anomalies and GP climate variability, this study diagnoses the key circulation anomalies through an analysis of SSTs and their influence on the atmosphere. Results show that during Pattern southern Great Plains (SGP) pluvial years, central tropical Pacific SST anomalies are coincident with key atmospheric anomalies across the Pacific basin and North America. During northern Great Plains (NGP) Pattern pluvial years, no specific pattern of oceanic anomalies emerges that forces the circulation anomaly feature inherent in specific NGP pluvial years. Utilizing the results for SGP pluvial years, a conceptual model is developed detailing the identified pathway for the occurrence of circulation patterns that are favorable for pluvial years over the SGP. Overall, results from this study show the importance of the identified SGP atmospheric anomaly signal and the potential for predictability of such events.
\end{abstract}

\section{Introduction}

The role of sea surface temperatures (SSTs) in weather and climate has been well studied and documented. From the most dominant mode of SST variability, El NiñoSouthern Oscillation (ENSO; e.g., Rasmusson and Carpenter 1982; Hoerling et al. 1997; Trenberth 1997; Harrison and Larkin 1998; Larkin and Harrison 2005a,b; Chiodi and Harrison 2013; Chen et al. 2014; L'Heureux et al. 2015; Yu et al. 2015; Guo et al. 2017) to the regional

\footnotetext{
Corresponding author: Paul Flanagan, pflanagan3@unl.edu
}

influences of western boundary currents (e.g., Nakamura et al. 2004; Wallace and Hobbs 1977; Kwon et al. 2010), a focus has been placed on explaining climate signals through modes of SST variability. This is especially true for North American climate, owing to the proximity to both the Pacific and Atlantic Oceans (e.g., Sanders 1986; Kuo et al. 1991; Reed et al. 1993, Findell and Delworth 2010). Primarily, efforts have utilized global to regional model simulations to categorize these teleconnections (e.g., Bates et al. 2001; Barsugli and Sardeshmukh 2002; Chen 2002; Schubert et al. 2009; Wang et al. 2010) along with observational studies (e.g., Deser and Wallace 1990; 
Hu and Feng 2001; Lau and Weng 2002; Lau et al. 2004; Ding and Wang 2005; Ruiz-Barradas and Nigam 2005; Frankignoul and Sennéchael 2007; Hu and Huang 2009; Ding et al. 2011; Ciancarelli et al. 2014; Seager and Hoerling 2014; Guo et al. 2017) that utilize advanced statistical methodologies to link modes of SST variability to North American climate.

While investigating statistical relationships is crucial in inferring impacts of SST anomalies on climate, the study of the physical atmospheric responses from these SST anomalies is just as crucial. The response of the atmosphere to canonical ENSO events has been well studied, with the anomalous Rossby wave train induced in the northern Pacific by anomalous latent heat release originating from the SST anomalies, leading to modifications to the Pacific and subtropical jet streams, with downstream impacts to the North American climate (e.g., Ting and Wang 1997; Seager et al. 2003; Schubert et al. 2004; Seager et al. 2005a,b; Mei and Wang 2011; Seager et al. 2014; Fernando et al. 2016; Pu et al. 2016). As moisture transport for central U.S. precipitation originates primarily from southern moisture sources (e.g., Helfand and Schubert 1995; Higgins et al. 1997; Ting and Wang 1997; Ruiz-Barradas and Nigam 2005; Berg et al. 2015), impacts of SST anomalies in the Pacific are primarily connected with anomalous synoptic activity in forcing precipitation anomalies over the region (i.e., the anomalous eddy activity owing to the shifts in the atmospheric circulation patterns over the North Pacific). While studies have mainly focused on the links between central U.S. climate and Pacific SST variability, additional studies have shown that tropical North Atlantic SST anomalies can also impact central United States climate (Enfield et al. 2001; Hoerling and Kumar 2003; Ruiz-Barradas and Nigam 2005; Seager et al. 2005a; Sutton and Hodson 2005; Schubert et al. 2009; Kushnir et al. 2010; Mei and Wang 2011; Seager et al. 2014). The anomalous convection over the tropical North Atlantic, similar to the tropical Pacific, releases anomalous latent heat, which in turn modifies circulation patterns over the tropical Atlantic (i.e., the tropical North Atlantic anticyclone; Kushnir et al. 2010). Anomalies to this feature directly impact flow patterns over the United States, as a stronger North Atlantic anticyclone will enhance southerly flow over the central United States and vice versa. Further, Caribbean and Gulf of Mexico SST anomalies can further impact moisture availability over the Great Plains (GP), owing to the evaporation of moisture directly into the southerly flow that dominates the region during the warm season (e.g., Wang 2007; Wang and Lee 2007; Martin and Schumacher 2011). With varying modes of SST and climate variability impacting circulation patterns, the combined effects of these patterns can strengthen or weaken the relationships between each other and their associated impacts on GP climate (Hu and Huang 2009; Schubert et al. 2009; Kushnir et al. 2010; Fernando et al. 2016; Pu et al. 2016; Schubert et al. 2016). Thus, the impacts of SST anomalies on the GP climate have been widely studied, especially in terms of the impacts of SST anomalies on the onset, duration, and intensity of drought. However, the linkages between excesses in precipitation and their associated anomalous atmospheric drivers have not been as widely investigated.

While previous research linking SST and central U.S. precipitation variability has focused on the occurrence of concurrent or time-lagged SST anomalies on precipitation patterns, few have focused specifically on the synoptic-scale drivers of these precipitation anomalies and their connections to SST anomalies. Flanagan et al. (2018) documented distinct atmospheric patterns linked to above-normal precipitation over the GP region (their Figs. 1a,b). Synoptic wave frequency over the southwestern United States showed signs of being crucial to southern Great Plains (SGP) above average precipitation (i.e., pluvial) years whereas northwestern U.S. synoptic wave intensity and its subsequent impact on atmospheric flow patterns were crucial to the occurrence of northern Great Plains (NGP) pluvial years. While the distinct atmospheric signals during so-called Pattern pluvial years (i.e., years that were found to be strongly linked to an atmospheric anomaly pattern) were diagnosed in Flanagan et al. (2018), they did not determine the sources of the atmospheric anomalies.

Thus, the purpose of this study is to diagnose the key circulation anomalies driving excessive precipitation during specific NGP and SGP pluvial years and determine the root causes that led to these circulation anomalies. The end goal is to complete the chain, to connect climate signals to the circulation anomalies that are driving the enhanced precipitation over the GP during specific pluvial years. To achieve this, this study will build on the findings of Flanagan et al. (2018) and link the identified atmospheric patterns from Flanagan et al. (2018) with larger-scale modes of climate variability, namely SSTs. While the roles of moisture transport, land-atmosphere interactions, internal atmospheric variability, and other atmospheric/ surface-based dynamics are likely important during GP pluvial years, the focus of this paper is to further diagnose the annual atmospheric anomaly patterns identified in Flanagan et al. (2018) to elucidate their likely origins. Further, it is recognized that other features outside the scope of the circulation anomalies noted in this paper can lead to GP precipitation anomalies, such as the AMO (Nigam et al. 2011) and PDO (Mantua and Hare 2002) as examples; these are outside the scope of this study. These 
results will aid in establishing fundamental pathways between SSTs, atmospheric patterns from GP pluvial years, and the precipitation that occurs, which can be used to improve the prediction of pluvial years in the GP.

\section{Data and methods}

\section{a. Datasets}

Pluvial years are defined using the same methodology as in Flanagan et al. (2018), with a year being identified as a pluvial if the annual precipitation amount over either the southern Great Plains (Texas, Oklahoma, and Kansas) or northern Great Plains (Nebraska, South Dakota, and North Dakota) is $10 \%$ above the annual climatological (1926-2010) mean. The pluvial years identified in the European Centre for Medium-Range Weather Forecasts (ECMWF) twentieth century reanalysis (ERA-20C; Poli et al. 2016) dataset are compared to pluvial years identified in Parameter-elevation Regressions on Independent Slopes Model (PRISM; Daly et al. 2000) observations and only years that are common to both lists are utilized as pluvial years in this study.

To facilitate the diagnosis of GP pluvial years, monthly-mean fields from the ERA-20C monthly and hourly datasets are chosen to represent atmospheric fields. This reanalysis product assimilates surface-based observations from 1900 to 2010 using a 4D-Var assimilation system to reanalyze historical weather signals and provide spatially continuous atmospheric and surface fields across the globe at a native resolution of $125 \mathrm{~km}$. For our study, a $2^{\circ} \times 2^{\circ}$ grid is used to maintain analysis consistency with Flanagan et al. (2018), with PRISM observations being regridded to this $2^{\circ} \times 2^{\circ}$ grid using local area averaging code within the NCAR Command Language (NCL). ERA-20C data also use the Hadley Centre Sea Ice and Sea Surface Temperature version 2 (HadISSTv2; Rayner et al. 2003) dataset to initialize the ocean model used for the reanalysis product. Analyses done in this study are replicated with both ERA-20C and HadISSTV2 SST fields to test for robustness, and results are nearly identical. Fields from 1926 to 2010 are annually averaged, consistent with Flanagan et al. (2018), who noted that ERA-20C precipitation fields lacked realism before 1926 over the central United States, seen in Poli et al. (2016). The ERA-20C dataset was chosen to facilitate comparisons between this study and the results from Flanagan et al. (2018).

\section{b. Calculating the eddy geopotential height index}

Key to this study is the identification of specific pluvial years driven by the atmospheric anomaly signal identified in Flanagan et al. (2018) for the NGP and SGP. Through the use of an eddy geopotential height (EGH) index, they identified pluvial years in which the atmospheric anomaly pattern was determined to be the primary driver of the excessive precipitation that occurred over that year, which they called Pattern pluvial years. Through the use of so-called Total pluvial years, defined as all pluvial years found using the pluvial definition described above, an index is created by projecting the EGH anomaly field for each year onto the Total EGH anomaly composite map for two different regions $\left(10^{\circ}-\right.$ $50^{\circ} \mathrm{N}, 130^{\circ}-90^{\circ} \mathrm{W}$ for SGP years; $30^{\circ}-50^{\circ} \mathrm{N}, 130^{\circ}-90^{\circ} \mathrm{W}$ for NGP years), where the Total EGH anomaly is the anomaly field created by averaging EGH over all pluvial years. Thus, this index represents when the NGP and SGP atmospheric anomaly patterns identified in Flanagan et al. (2018) are more active (higher value of the index) or quiescent (lower values of the index). The use of an index based off of EGH instead of precipitation was done in order to isolate and identify pluvial years in which the EGH anomaly signal seen in the Total pluvial EGH composite was more active compared to other pluvial years. This index was particularly important in Flanagan et al. (2018) in separating the pluvial years that most closely resembled the composite atmospheric pluvial signal (Pattern pluvial years) and those that deviated from this overall atmospheric signal. As such, Pattern pluvial years were found by setting a threshold for the EGH index $(0.5 \sigma)$ and identifying any pluvial year which crossed this threshold, thus gathering all years which display a stronger anomalous atmospheric forcing for a pluvial over either the NGP or SGP. For more details of the calculation and use of this index refer to Flanagan et al. (2018).

\section{c. Synoptic wave event classification scheme}

Given the results of Flanagan et al. (2018) relating to the occurrence of GP Pattern pluvial years and synoptic wave features, we developed a method to identify synoptic waves in the ERA-20C dataset. As synoptic wave features are distinguished by their curvature and influence on the flow pattern, relative vorticity and the geopotential height anomalies are chosen to identify synoptic wave events over two different regions, one for the SGP $\left(20^{\circ}-40^{\circ} \mathrm{N}, 130^{\circ}-100^{\circ} \mathrm{W}\right.$; southwestern United States $)$ and one for the NGP $\left(40^{\circ}-60^{\circ} \mathrm{N}, 130^{\circ}-100^{\circ} \mathrm{W}\right.$; northwestern United States). The different regions are associated with the anomalous synoptic signals crucial to the occurrence of Pattern pluvial years found in Flanagan et al. (2018) (i.e., southwestern United States for SGP and the northwestern United States for the NGP).

To identify synoptic waves, thresholds (noted below) are set to classify events from the 0000 UTC 500-mb $(1 \mathrm{mb}=$ $1 \mathrm{hPa}$ ) geopotential height and relative vorticity ERA-20C fields. After utilizing a high-pass 10-day filter to isolate the 
TABLE 1. List of years averaged over to derive each composite plot. Pattern years are found using the methodology defined within the Flanagan et al. (2018) study. Also included is the list of all pluvial years from the ERA-20C dataset found in Flanagan et al. (2018).

\begin{tabular}{llc}
\hline \hline & \multicolumn{1}{c}{ SGP } & \multicolumn{1}{c}{ NGP } \\
\hline All pluvial years & $1926,1941,1957,1968,1974,1979,1987,1990$, & $1941,1951,1962,1965,1977,1982,1986,1993$, \\
& $1991,1992,1997,2002,2004,2007,2009$ & $1995,1998,2005,2007,2008,2009,2010$ \\
Pattern years & $1926,1941,1987,1991,1992,1997,2002,2004$ & $1951,1982,1998,2008,2010$ \\
Event composites & $1926,1987,1992,1997,2002,2004$ & $1982,2008,2010$ \\
$\quad$ (intensity) & $1926,1987,1992,2002,2004$ & $1951,1998,2008,2010$ \\
Event composites & & \\
$\quad$ (synoptic waves) & & \\
\hline
\end{tabular}

synoptic time scale features at each grid point, the geopotential height and vorticity data are standardized, to facilitate a comparison between the two regions. Filtering is completed by creating 201 individual weights using a Lanczos filter (Duchon 1979) included in the NCAR Command Language and then applying these weights at each grid point. The Lanczos filter, in frequency space, is represented by an approximate step function of near 0 at frequencies lower than 10 days and near 1 on frequencies higher than 10 days, as in Duchon (1979) (their Fig. 2). To identify synoptic waves the average geopotential height anomaly within the region is required to be at least $-0.5 \sigma$ or below, with at least one grid point with a relative vorticity value of at least $1.5 \sigma$ and at least one grid point with a geopotential height value of at least $-1.5 \sigma$. As the values are filtered and standardized, the $\pm 1.5 \sigma$ values represent strong deviations from the typical flow pattern and given the sign of relative vorticity and geopotential height anomalies the events identified using these thresholds are Northern Hemisphere troughs. To investigate the intensity of the synoptic waves, the minimum grid point standardized geopotential height anomaly value within the boxed area is taken whenever a synoptic wave event is identified. Through an analysis of the synoptic wave events determined by varying the thresholds, the final thresholds are determined by their ability to represent synoptic waves (troughs) and the reduction of false wave events (ridges).

\section{d. Composite and regression analysis}

For this study, two different statistical methods are implemented: 1) the composite analysis of surface and atmospheric fields and 2) linear regression analysis using the EGH anomaly index. Composites are created for SSTs, 250-mb streamfunction, and 500-mb EGH anomalies for Pattern pluvial years (Table 1). SSTs are investigated owing to their strong connection to global climate variability, while the streamfunction variable is chosen to illustrate the effect of SSTs on the stationary wave signal during pluvial years. Seasonal composites including December-February (DJF), March-May (MAM), June-August (JJA), and September-November (SON) values of SST and streamfunction are also analyzed to detail the seasonal persistence of the SST and atmospheric signals found during Pattern pluvial years. Further, composites are created for years with above average number of synoptic wave events and those with more intense synoptic waves (Table 1). These subsets of Pattern pluvial years were chosen by finding Pattern pluvial years with an above average number of synoptic waves and Pattern pluvial years in which the annually averaged intensity (lowest standardized geopotential height anomaly found within the identified wave) was higher than the annual climatology. These are created to compare the atmospheric and surface fields during these Pattern pluvial years to the composites created from the list of all Pattern pluvial years.

Linear regression analysis is used to diagnose the contemporaneous correlation between the EGH anomaly index and relevant surface (SST and annual accumulated precipitation) and atmospheric (250-mb wind components and 250-mb streamfunction) fields. The EGH index and all ERA-20C fields are standardized and detrended and the annual cycle was removed prior to linear regression. Significance testing for statistical relationships is done using a 1000-iteration bootstrap test (by grid point) and using a $90 \%$ two-tailed threshold.

\section{Diagnosis of synoptic waves during Great Plains Pattern pluvial years}

\section{a. Synoptic wave event statistics}

Owing to the importance of synoptic waves with regard to the occurrence of Pattern pluvial years (Flanagan et al. 2018), the frequency and intensity of synoptic waves over the southwestern and northwestern United States are investigated for the SGP and NGP, respectively. For all years within the ERA-20C dataset, an average of 52 (62) synoptic wave events per year occur over the southwestern (northwestern) United States as defined by our classification scheme. When the 
average number of events per year during pluvial years is compared with all years, the results are nearly identical for both regions (Table 2). However, when only Pattern years for both regions are considered, the results yielded increased totals with 63 (81) events on average per Pattern year over the southwestern (northwestern) United States. The difference in means between all years and Pattern years is statistically significant for both regions, consistent with the findings of Flanagan et al. (2018).

When the intensity of synoptic waves during pluvial years is considered, the results are different compared to the frequency of these waves. Overall, the average of the minimum value in the southwestern (northwestern) United States is approximately $-3.3 \sigma(-2.7 \sigma)$ (Table 2 ). For all pluvial years, this average did not significantly change for either region. For Pattern pluvial years, the mean intensity for all southwestern waves increases to approximately $-3.5 \sigma$ and for the northwest no change is seen between all pluvial years and Pattern pluvial years. However, only the results for SGP years are statistically significant. These statistics represent a first step in determining if key results pertaining to synoptic waves for SGP and NGP Pattern pluvial years are valid. Results show that the frequency and intensity of these waves are important to the occurrence of a SGP Pattern pluvial year, whereas for NGP Pattern pluvial years the results are less conclusive, with the statistics showing little changes and no statistical significance. Thus, it is not possible to conclude if the statement about synoptic wave intensity during NGP Pattern pluvial years over the northwestern United States is crucial to a NGP Pattern pluvial year.

\section{b. Event classification composites}

While the statistics of the synoptic wave and intensity provide information about the dynamic atmospheric contributors to pluvial years, it does not wholly answer the question into the importance of either. To thoroughly investigate the relationship between synoptic wave frequency and intensity with Pattern pluvial years, a subset of Pattern pluvial years from the NGP and SGP will be defined having an above average amount of synoptic waves or an above average synoptic wave intensity. This will highlight the relative importance of these features of synoptic waves for the region, through the number of Pattern pluvial years that show above average frequency or intensity, as well as detailing key atmospheric features that are seen during Pattern pluvial years with above average synoptic characteristics. For SGP Pattern pluvial years with an above average synoptic wave years, the negative EGH anomaly signals (Fig. 1c) are similar to that of the Pattern
TABLE 2. Average number of synoptic wave events (troughs) per year and intensity of those waves. Rounding was completed to represent events rather than the decimal average; the actual average is in parentheses below the rounded number.

\begin{tabular}{lrr}
\hline \hline & SGP & \multicolumn{1}{c}{ NGP } \\
\hline $\begin{array}{l}\text { Synoptic wave events } \\
\text { All }\end{array}$ & $52(51.5)$ & $62(61.5)$ \\
Pluvial & $52(51.6)$ & $61(60.5)$ \\
Pattern & $61^{\mathrm{a}}(60.9)$ & $80^{\mathrm{a}}(79.6)$ \\
Synoptic wave intensity & \\
All & $-3.3 \sigma(-3.34 \sigma)$ & $-2.7 \sigma(-2.66 \sigma)$ \\
Pluvial & $-3.4 \sigma^{\mathrm{a}}(-3.41 \sigma)$ & $-2.7 \sigma(-2.69 \sigma)$ \\
Pattern & $3.5 \sigma^{\mathrm{a}}(-3.47 \sigma)$ & $-2.7 \sigma(-2.72 \sigma)$ \\
\hline
\end{tabular}

${ }^{a}$ Statistically significantly different from the annual mean using a $90 \%$ one-tailed bootstrap significance test.

composites from Flanagan et al. (2018) (Fig. 1a). An area of negative EGH anomalies exists over the southwestern United States with a larger magnitude negative anomaly over the North Pacific Ocean. The SGP EGH anomaly composite during Pattern pluvial years with an above average synoptic wave intensity years (Fig. 1e) shows nearly the exact same EGH anomaly features seen during Pattern pluvial years with an above average number of synoptic waves (Fig. 1c) and for all SGP Pattern pluvial years (Fig. 1a). This is likely due to the importance of both the intensity and frequency of synoptic waves over the southwestern United States, which is seen from the nearly identical list of Pattern pluvial years in both composites (Table 1). Thus, for SGP Pattern pluvial years, the contributions from an increased number of southwestern U.S. synoptic waves and the intensity of these wave appear equally important for the occurrence of a SGP Pattern pluvial year to occur, owing to the strong similarities shown between years with an above average number of waves (Fig. 1c) and their intensity (Fig. 1e) and the overall SGP Pattern pluvial year EGH composite (Fig. 1a).

For SGP Pattern pluvial years with an above average synoptic wave years, a significant SST anomaly (Fig. 2a) signal exists across the central tropical Pacific. Previous studies have shown a link between enhanced southern U.S. precipitation and El Niño events (e.g., Ropelewski and Halpert 1986, 1987, 1989; Gershunov and Barnett 1998; Dai and Wigley 2000; Larkin and Harrison 2005a,b). However, this composite SST feature of warm anomalies resembles more of a central Pacific (CP) ENSO event (e.g., Larkin and Harrison 2005a,b; Ashok et al. 2007; Yu and Kao 2007; Kao and Yu 2009; Kug et al. 2009; Fang and Mu 2018), with a maximum SST anomaly located in the central tropical Pacific Ocean. Thus, the atmospheric response is also different from canonical ENSO events (e.g., Barsugli and Sardeshmukh 2002). 



FIG. 1. ERA-20C 500-mb eddy geopotential height (EGH) anomalies (a) from Flanagan et al. (2018) for SGP Pattern pluvial years, (b) from Flanagan et al. (2018) for NGP Pattern pluvial years, (c) for SGP Pattern pluvial years with an above average number of synoptic waves, (d) for NGP Pattern pluvial years with an above average number of synoptic waves, (e) for SGP Pattern pluvial years with an above average synoptic wave intensity, and (f) for NGP Pattern pluvial years with an above average synoptic wave intensity. Contours are from -16 to $16 \mathrm{~m}$ every $4 \mathrm{~m}$, with stippling represented grid points that are statistically significant at the $90 \%$ level. Black boxes in (a) and (b) represent areas used to compute the EGH anomaly index for the (a) SGP and (b) NGP. Black boxes in (c)-(f) represent the areas used to identify synoptic waves for the event classification scheme for the (c),(e) SGP and (d),(f) NGP.

Indeed, Garfinkel et al. (2013) showed that during CP warm ENSO events, the North Pacific low is located farther south compared to a typical El Niño event. As such, this southward shift in the low center would also induce a southward shift in the Pacific jet stream, thus impacting the synoptic wave signal over the southern United States. Note that our composites likely contain both CP and canonical (eastern Pacific) ENSO warm events. However, because of the relative magnitude of the anomalies in the central Pacific, CP warm ENSO events likely dominate the atmospheric anomalies and synoptic wave frequency. Figure $2 \mathrm{a}$ also presents the streamfunction composite for the SGP above average synoptic wave activity years. The composite illustrates a large area of negative anomalies across the Northern Hemisphere, with the largest negative anomalies over the North Pacific and the southwestern United States.
The anomaly gradient over the central North Pacific shows that the jet stream is shifted anomalously southward, facilitating an increase in the occurrence of synoptic waves over the southern United States (e.g., Trenberth et al. 1998; Neelin 2011; Wang et al. 2013; Wirth et al. 2018).

Figure 2c details SST and streamfunction anomalies during SGP Pattern pluvial years with above average intensity synoptic waves. The anomalies during above average intensity SGP Pattern pluvial years are similar to the features seen in the above average synoptic wave SGP Pattern pluvial years, with an increased area of SST anomalies in the central and eastern tropical Pacific along with a slight increase in the negative streamfunction anomalies across the Northern Hemisphere. Thus, both our statistical and composite analysis show that the frequency and intensity of southwestern U.S. 500-mb 

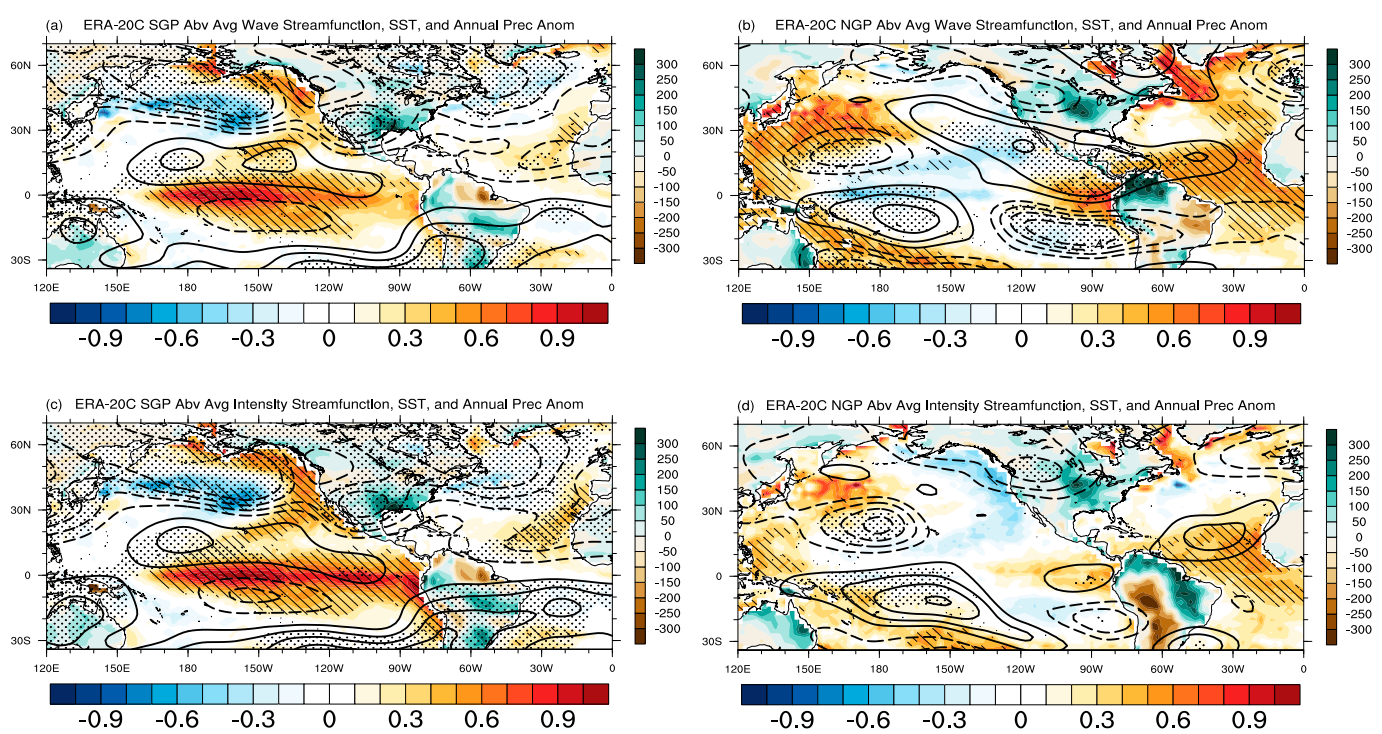

FIG. 2. SST $\left({ }^{\circ} \mathrm{C}\right)$; shaded contours) and $250-\mathrm{mb}$ streamfunction $\left(10^{-6} \mathrm{~m}^{2} \mathrm{~s}^{-1}\right)$ anomalies for (a) SGP Pattern pluvial years with an above average number of synoptic waves (synoptic wave event years), (b) NGP Pattern pluvial years with an above average number of synoptic waves (synoptic wave event years), (c) SGP Pattern pluvial years with an above average synoptic wave intensity (intensity event years), and (d) NGP Pattern pluvial years with an above average synoptic wave intensity (intensity event years). Contour interval $0.1^{\circ} \mathrm{C}$ for SST anomalies and $1 \times 10^{-6} \mathrm{~m}^{2} \mathrm{~s}^{-1}$ for streamfunction anomalies. Solid (dashed) contours represent positive (negative) streamfunction anomalies; zero contour omitted. Statistical significance at the $90 \%$ level is noted by stippling for the streamfunction anomalies and dashed areas for the SST anomalies. Blue/red color filled contours over the oceans are for SST anomalies and brown/green color filled contours over land are for annual precipitation total anomalies.

synoptic waves are important for the occurrence of an SGP Pattern pluvial year. This is a slightly different conclusion than that seen by Flanagan et al. (2018), who noted that the frequency of synoptic waves in this region were important for these specific pluvial years.

For the NGP, Pattern pluvial years with an above average number of synoptic waves (Fig. 1d) show a similar signal as that seen in Flanagan et al. (2018) for NGP Pattern pluvial years (Fig. 1b). In Fig. 1d, the area of negative EGH anomalies is located farther to the north compared to EGH anomalies during NGP Pattern pluvial years (Fig. 1b), over northwestern North America, and of increased magnitude especially farther upstream and downstream of the northwestern United States. As for SST and streamfunction, NGP Pattern pluvial years with an above average number of synoptic waves (Fig. 2b) show a large area of positive SST anomalies in the Atlantic Ocean basin, associated with an enhanced subtropical high. In the Pacific, SST anomalies in the tropics are less conclusive, with an area of positive SST anomalies in the eastern Pacific and negative anomalies in the central Pacific, reminiscent of a central Pacific La Niña, associated with decreased streamfunction over the central North Pacific. Results from the NGP Pattern pluvial years with above average intensity synoptic waves are no more conclusive. EGH anomalies during above average intensity NGP Pattern pluvial years (Fig. 1f) show large similarities to the EGH anomalies seen during NGP Pattern pluvial years (Fig. 1b), with the area of negative EGH anomalies over the northwestern United States and a positive anomaly over the western North Pacific. SST anomalies (Fig. 2d) during NGP Pattern pluvial years with above average intensity shows few significant SST anomaly signals across the Pacific Ocean basin, with a large area of positive anomalies in the tropical Atlantic, again associated with an enhanced subtropical high. Thus, while the statistical analysis shows that only an above average number of synoptic waves over the northwestern United States is important for NGP Pattern pluvial years, the composites of EGH, SST, and streamfunction anomalies show that the intensity of these synoptic waves could also be important to their occurrence. With the results from Flanagan et al. (2018) implying that intensity was the important factor for NGP Pattern pluvial years, our results again do not support such a statement with further work required to reach a definitive conclusion into the importance of synoptic wave characteristics to NGP Pattern pluvial years. With the results from the statistics showing that intensity is not a crucial factor in the existence of an NGP Pattern pluvial year, it is likely that the comparatively larger EGH height anomalies found during NGP Pattern 
pluvial years compared to SGP Pattern pluvial years are due to the difference in location. Thus, troughs during in the northwestern United States are deeper than in the southwestern United States, which would inflate the anomalies.

\section{Diagnosis of Great Plains Pattern pluvial years}

\section{a. SST and streamfunction composites}

Through an investigation into the frequency and intensity of synoptic waves, results show a connection between wave frequency and key features of Pattern pluvial years (i.e., confirming that synoptic wave frequency is crucial for the occurrence of GP Pattern pluvial years) with intensity being important for the SGP. However, these results do not show the state of the ocean or atmosphere during Pattern years specifically. Thus, analysis detailing the state of the ocean surface and atmosphere is still needed to definitively show the links between Pattern pluvial years and SST signals.

The composite of SST anomalies during SGP Pattern years shows a large area of positive SST anomalies across the tropical Pacific (Fig. 3). Similar to the SGP Pattern pluvial year above average synoptic wave event SST composite, the center of largest magnitude anomalies is located over the central tropical Pacific. When the SGP analysis is broken into seasonal composites of SST (Figs. 3b-e), the same general signal appears in each season; SST anomalies in DJF (Fig. 3b) occurred mainly over the central tropical Pacific without any signal over the eastern tropical Pacific, whereas MAM SST anomalies (Fig. 3c) show that the center of warm SST anomalies shifted eastward. This composite anomaly signal continues during JJA (Fig. 3d) and SON (Fig. 3e). However, by SON, the SST composite signal resembles more of a canonical El Niño event. During JJA (Fig. 3d) and SON (Fig. 3e) an area of positive SST anomalies across the subtropical Atlantic Ocean, off the coast of Africa, is analyzed. As these exist in the region where SST anomalies support or hinder the subtropical Atlantic high, the expected response from these SST anomalies would be a strengthened subtropical ridge in the Atlantic, which is not seen. Thus, the seasonality of SSTs during Pattern pluvial years is important, given the seasonality of precipitation within these pluvial years. Precipitation data for each season (Fig. 3) show anomalies across the SGP for each season, with DJF (Fig. 3b) and MAM (Fig. 3c) showing anomalies across the southern portions of the SGP and JJA (Fig. 3d) and SON (Fig. 3e) having anomalies in the northern portion of the SGP. These results match the seasonality of pluvial months seen during pluvial years from Christian et al. (2015). Their study showed that pluvial months could occur at any time of the year in the SGP, although preferentially they occurred during February, March, October, and November.

During SGP Pattern pluvial years (Fig. 3), negative streamfunction anomalies cover most of the Northern Hemisphere, with the largest magnitudes over the northern Pacific and across the southwestern and south central North America (Fig. 3a). A positive anomaly area in the tropical Pacific, with a gradient between negative anomalies across the northern Pacific, shows that the Pacific jet stream is located farther south of its climatological position. As the jet stream is predominantly a zone of strong westerly winds, these westerly propagating waves will be concentrated along this narrow band of strong winds. Thus, these results agree with our event composite results. Both analyses show a shift in the North Pacific jet stream resulting from anomalies in the atmospheric height regime.

Seasonal composites of streamfunction anomalies during SGP Pattern pluvial years yield the same overall signal during all four seasons with minor differences, especially during DJF (Fig. 3b) and MAM (Fig. 3c). During JJA (Fig. 3d), we still see the negative streamfunction anomalies over the tropical Pacific and the North Pacific; however, positive streamfunction anomalies between the two regions are no longer present. During SON (Fig. 3e), a signal resembling that of the DJF and MAM streamfunction anomalies exists, with reduced magnitudes of the positive streamfunction anomalies in the lower latitudes over the Pacific Ocean being the main difference. From our seasonal analysis of SST and streamfunction we have shown that the spring (MAM), fall (SON), and winter (DJF) seasons correspond to the times of year in which the largest SST anomalies are seen coincident with the strongest atmospheric anomalies, although the atmospheric signal during fall (SON) is not as strong as seen in the spring or winter. Thus, while the seasonal signal of SST and streamfunction anomalies are persistent throughout the year, they are likely impacting SGP precipitation in different ways during different seasons. While precipitation anomalies are seen during each season of Pattern pluvial years, their location shifts farther to the north as the year passes. This shift occurs with shifts in the center of negative streamfunction anomalies across the southwestern United States. As the year passes, this center shifts slightly to the north along with the center of the precipitation anomalies across the SGP.

During NGP Pattern pluvial years, an area of positive SST anomalies (Fig. 4) appears off the western coast of tropical South America (Fig. 4a). Additionally, positive anomalies off the coast of Japan show that the 

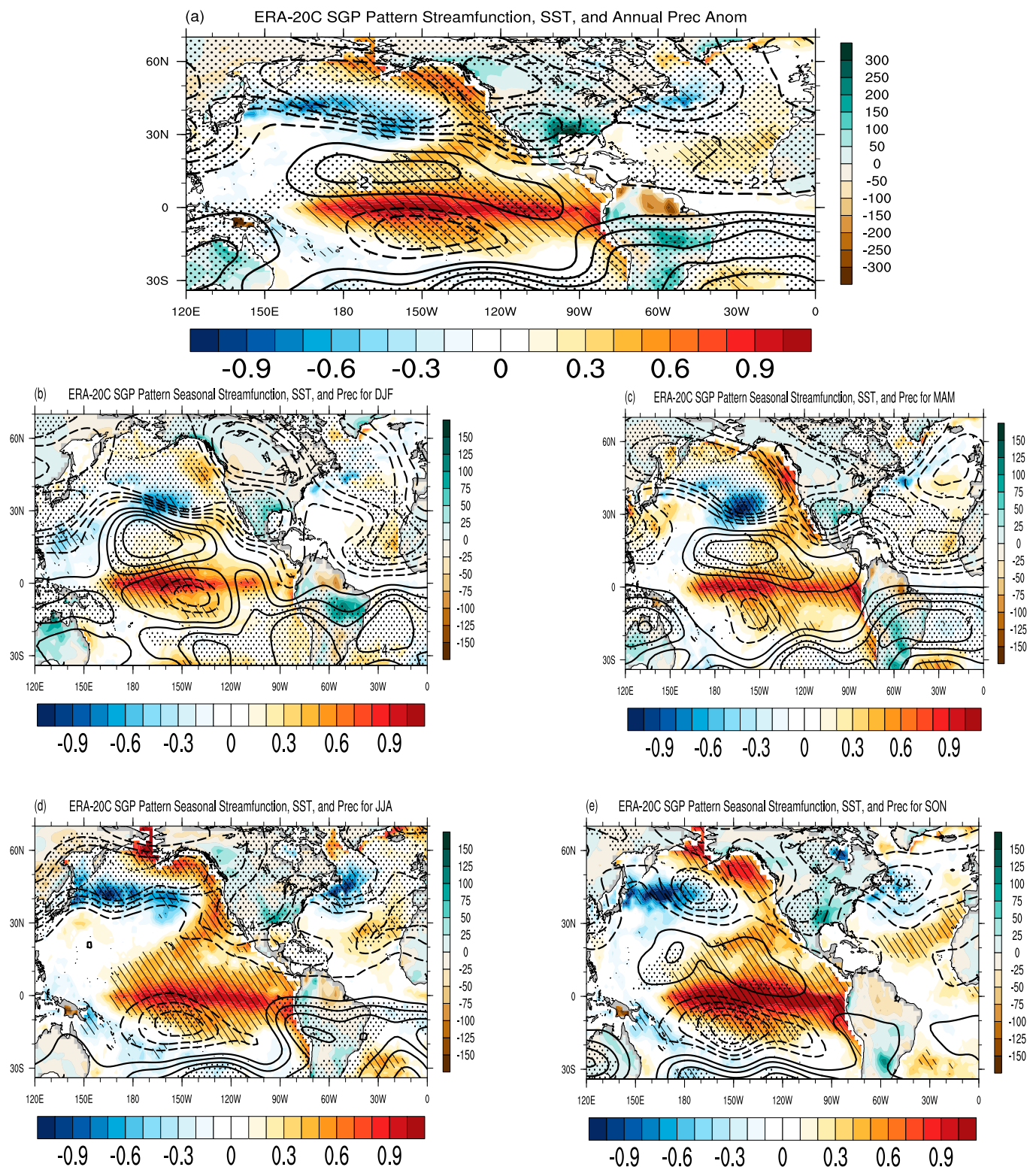

FIG. 3. SGP Pattern pluvial year SST and 250-mb streamfunction anomalies (a) annual composite and seasonal composites during Pattern pluvial years for (b) DJF, (c) MAM, (d) JJA, and (e) SON. Color shading is used for the sea surface temperature anomalies $\left({ }^{\circ} \mathrm{C}\right)$, contoured from -1 to 1 by 0.1 and contours are used for the streamfunction anomalies $\left(\mathrm{m}^{2} \mathrm{~s}^{-1} \times 10^{-6}\right)$, contoured from -4 to 4 by 1 . Statistical significance at the $90 \%$ level is noted by stippling for the streamfunction anomalies and dashed areas for the sea surface temperature anomalies. Contours for precipitation are in green from (a) -300 to 300 by $50 \mathrm{~mm} \mathrm{yr}^{-1}$ and (b)-(e) -150 to 150 by $25 \mathrm{~mm} \mathrm{yr}^{-1}$. Blue/red color filled contours over the oceans are for SST anomalies and brown/green color filled contours over land are for annual precipitation total anomalies.

Kuroshio-Oyashio Extension (KOE) SST region could be involved in NGP Pattern pluvial years. These KOE SST anomalies may work to increase the baroclinicity across the North Pacific, increasing cyclogenesis, and maintaining the storm-track (jet stream) location over the North Pacific (Kwon et al. 2010; Ma et al. 2015, 2017).
The seasonal composites of SST anomalies for NGP Pattern years yield statistically significant SST anomalies in the west-central Pacific and KOE regions during DJF (Fig. 4b), JJA (Fig. 4d), and SON (Fig. 4e) and an eastern tropical Pacific warm signal during MAM (Fig. 4c). The most persistent and significant anomalies in the NGP SST composite, however, appear in the 


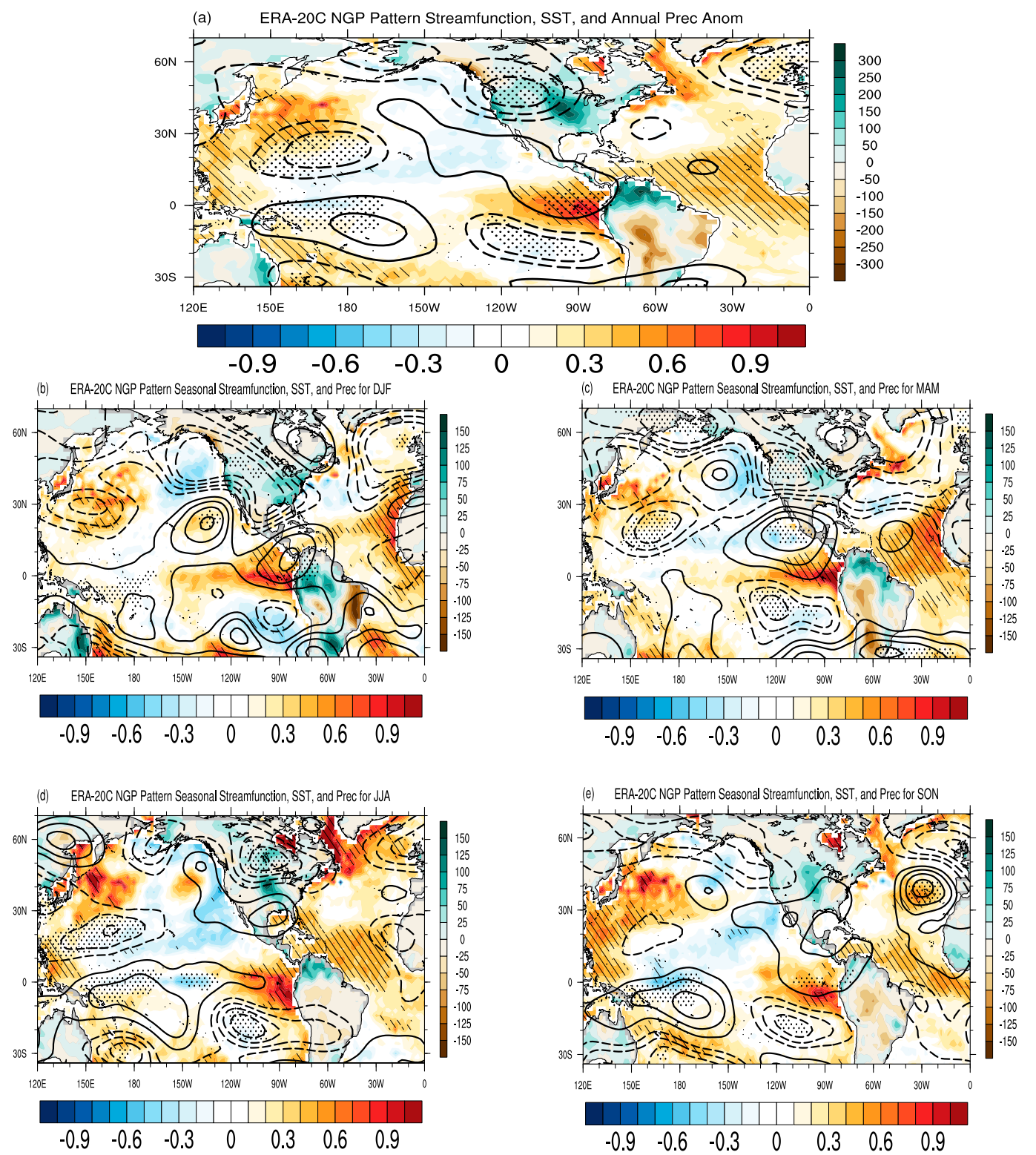

FIG. 4. NGP Pattern pluvial year SST and 250-mb streamfunction anomalies (a) annual composite and seasonal composites during Pattern pluvial years for (b) DJF, (c) MAM, (d) JJA, and (e) SON. Color shading is used for the sea surface temperature anomalies $\left({ }^{\circ} \mathrm{C}\right)$, contoured from -1 to 1 by 0.1 and contours are used for the streamfunction anomalies $\left(\mathrm{m}^{2} \mathrm{~s}^{-1} \times 10^{-6}\right)$, contoured from -4 to 4 by 1 . Statistical significance at the $90 \%$ level is noted by stippling for the streamfunction anomalies and dashed areas for the sea surface temperature anomalies. Contours for precipitation are in green from (a) -300 to 300 by $50 \mathrm{~mm} \mathrm{yr}^{-1}$ and (b)-(e) -150 to 150 by $25 \mathrm{~mm} \mathrm{yr}^{-1}$. Blue/red color filled contours over the oceans are for SST anomalies and brown/green color filled contours over land are for annual precipitation total anomalies.

tropical Atlantic during all seasons, along with a positive anomaly signal over the Caribbean during JJA (Fig. 4d). Precipitation anomalies during each season (Fig. 4) show positive anomalies across the NGP, with the largest anomalies occurring during JJA (Fig. 4d) and SON (Fig. 4e). During the warm season, this result does not similarly compare with the seasonal probability of pluvial months from Christian et al. (2015). Their study shows that a majority of the excessive rainfall occurs during the warm or convective season of the NGP, from March to July. Given the time of year of the greatest precipitation anomalies during NGP Pattern pluvial years, it is possible that a combination of anomalous convective rainfall (JJA) in addition to anomalous 
synoptically forced rainfall (SON) occurs to create the anomalies seen during NGP Pattern pluvial years. However, given the lack SST signal linked to the anomalous atmospheric signal key to NGP Pattern pluvial years, it is likely that the occurrence of NGP Pattern pluvial years is related to anomalous convective activity and moisture transport, scales that are too small for this study. Further, the western tropical Atlantic SST warm anomalies seen in JJA (Fig. 4d) likely have an influence on moisture transport through enhancement of low-level moisture into the low-level jet (e.g., Oglesby et al. 1989; Schubert et al. 2008; Knippertz and Wernli 2010), which provides more evidence that moisture transport is a key feature during NGP Pattern pluvial years.

During NGP Pattern pluvial years (Fig. 4a), an area of negative streamfunction anomalies lies across northern North America, representative of the negative height anomalies that define this pattern in Flanagan et al. (2018), but there is a lack of defined anomalies across most of the Northern Hemisphere during these years. Further, the seasonal streamfunction anomalies show a more variable signal. During DJF (Fig. 4b) and MAM (Fig. 4c) negative anomalies are seen over the northwestern United States, during JJA (Fig. 4d) these anomalies shift farther to the east and are broader, and during SON (Fig. 4e) no significant streamfunction anomaly feature is noted. While negative heights are seen over the northwestern United States during DJF, MAM, and JJA, the signals are quite different during each season.

\section{b. Eddy geopotential height index linear regression analysis}

While composite analyses detailed the linkages between Pacific SSTs and the anomalous circulation signals that define Pattern pluvial years, we now investigate the linear facets of these connections. We conduct linear regression and correlation analysis using annually averaged upper tropospheric wind fields and SSTs and the Flanagan et al. (2018) standardized EGH anomaly indices (one for NGP and one for SGP) as the base indices. Regression of SST anomalies onto the standardized SGP EGH index (Fig. 5a) illustrates positive SST anomalies across the tropical Pacific, with the largest anomalies in the central tropical Pacific. Statistically significant negative SST anomalies also exist in the North Pacific, along with an area of SST anomalies in the subtropical Atlantic. The regression signal closely resembles the Pattern composite (Fig. 3a) and the SGP above average synoptic wave event SST composite (Fig. 2a), but with higher magnitude. The Pacific Ocean signal as a whole resembles that of the PDO, a feature that has been linked in its warm phase to GP precipitation $(\mathrm{Hu}$ and Huang 2009). However, as the PDO is a low-frequency oceanic signal (e.g., Mantua et al. 1997; Newman et al. 2003; Schneider and Cornuelle 2005; Mills and Walsh 2013; Newman et al. 2016), the methodology used in this study may mask the comparatively higher-frequency ENSO signal, which would not emerge strongly when annualmean fields are used to compute linear statistics. Further, as SGP precipitation is, in part, linked to the PDO (e.g., Mantua and Hare 2002; Hu and Huang 2009), and the EGH index is inherently linked to SGP precipitation, this could be causing the PDO signal to become dominant when looking at climate-scale linear statistics. The Atlantic signal does not appear associated with an increased subtropical ridge, as expected; however, the area of negative streamfunction anomalies across the southern subtropical North Atlantic basin shows that the subtropical high is likely shifted during these years farther to the north and west coincident with this region of positive SST anomalies seen in the subtropical Atlantic.

The regression of 250-mb streamfunction onto the SGP EGH index (Fig. 5b) shows the negative height anomaly signal over the northern North Pacific and North America seen in the in the above average synoptic wave event and Pattern streamfunction composites (i.e., Figs. 2a and 3a). The SGP streamfunction regression plot shows that during years in which the SGP EGH index is higher, streamfunction across the tropical $\mathrm{Pa}$ cific will be lower, south of Hawaii will see stronger ridges, and across the North Pacific Ocean basin troughs will be deeper, including across the southern United States. This consistent signal in the Pacific SST and streamfunction analyses suggests a link between SST and streamfunction anomalies during SGP Pattern pluvial years. As seen in the streamfunction plots (Fig. 5b) the SST signal is coincident with a gradient in streamfunction anomalies, located near $30^{\circ} \mathrm{N}$ over the Pacific Ocean, signifying the shift in the jet stream. Further, the 250-mb zonal wind anomalies (Fig. 5c) are analyzed to determine if a consistent shift in the jet occurs. The zonal wind anomaly regressions show that during years with an enhanced SGP EGH index higher zonal winds are present across the North Pacific Ocean basin and the southern United States. Thus, the $u$ wind field shows a corresponding shift in the location of the jet stream during years in which the EGH anomaly index is higher. Last, precipitation anomalies associated with the SGP EGH index show a broad area of positive precipitation anomalies across the southern United States, with negative anomalies over the northwestern United States. The enhanced region of precipitation over the North Pacific Ocean and tropical Pacific, along with the enhanced precipitation over the southern United States, 



FIG. 5. 1926-2010 regression of (a) SST $\left({ }^{\circ} \mathrm{C}\right)$, (b) 250-mb streamfunction $\left(\mathrm{m}^{2} \mathrm{~s}^{-1} \times 10^{-6}\right)$, (c) 250-mb $u$-wind component (m s $\left.{ }^{-1}\right)$, and (d) annual total precipitation $\left(\mathrm{mm} \mathrm{yr}^{-1}\right.$ ) onto the standardized SGP EGH index (shown in right panel); contour interval 0.1; zero contour omitted. Stippled regions indicate regression coefficients that are statistically significant at the $90 \%$ level. Contour interval in (d) is 0.2 .

detail the enhanced Pacific and subtropical jet and the warm tropical Pacific SST anomalies that occur concurrently.

The NGP SST regression coefficient plot (Fig. 6a) resembles the NGP Pattern SST composites (Fig. 4a) with higher NGP EGH index years having warmer SSTs over the western North Pacific and lower SSTs across the eastern west Pacific, although Fig. 6a does not detail the signal seen in the tropics in Fig. 4a. Unlike the SGP, the tropical Pacific is devoid of significant SST anomalies. Thus, the NGP Pattern pluvial year atmospheric signal is not (linearly) linked with the tropical Pacific or Atlantic. During higher NGP EGH index years, decreased streamfunction (Fig. 6b) over the northwestern United States depicts a height anomaly signal matching that of the NGP pattern in Flanagan et al. (2018), with 

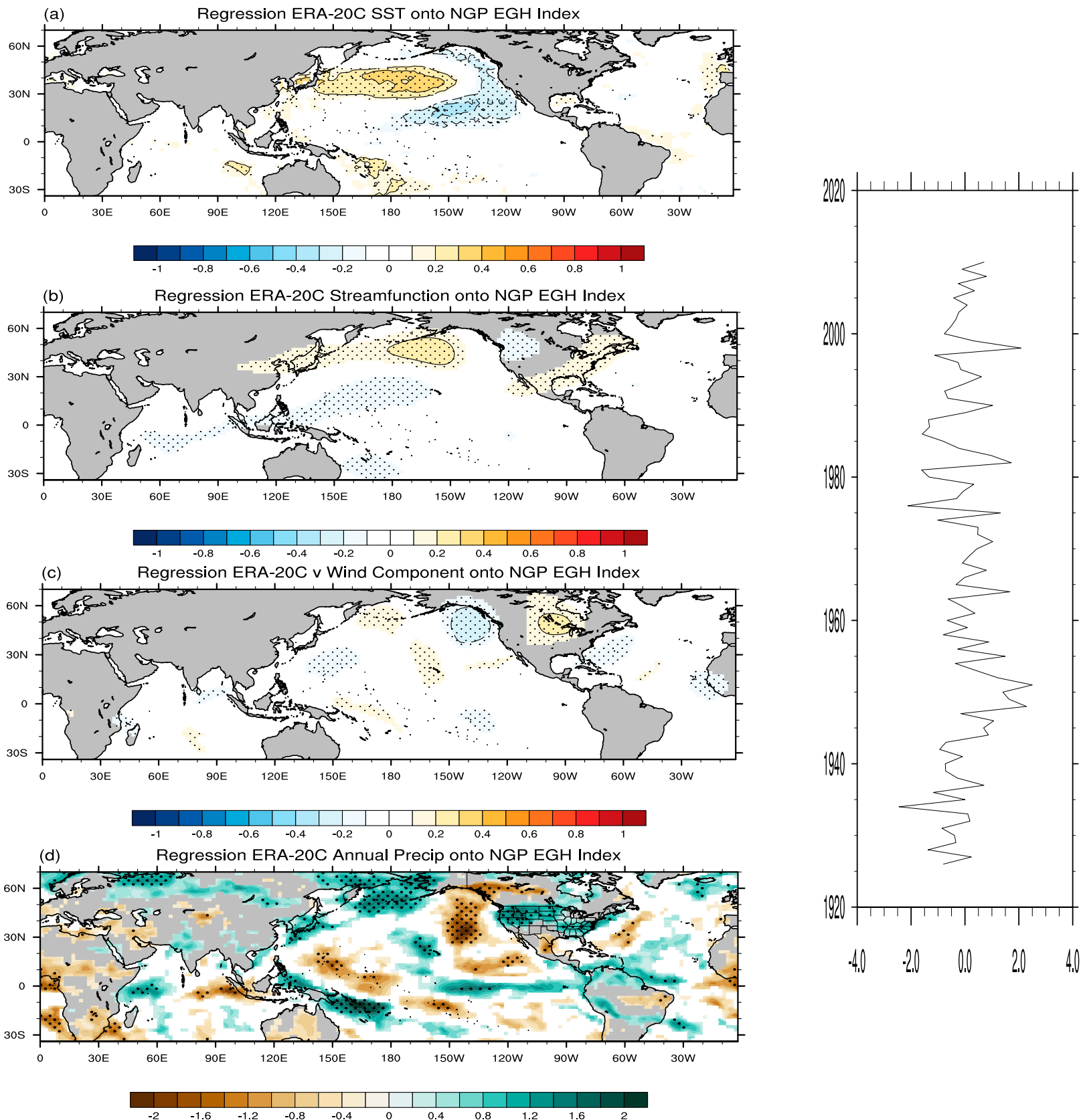

FIG. 6. 1926-2010 Regression of (a) SST $\left({ }^{\circ} \mathrm{C}\right)$, (b) 250-mb streamfunction $\left(\mathrm{m}^{2} \mathrm{~s}^{-1} \times 10^{-6}\right)$, (c) 250-mb $v$-wind component (m s $\left.{ }^{-1}\right)$, and (d) annual total precipitation $\left(\mathrm{mm} \mathrm{yr}^{-1}\right.$ ) onto the standardized NGP EGH index (shown in right panel); contour interval 0.1; zero contour omitted. Stippled regions indicate regression coefficients that are statistically significant at the $90 \%$ level. Contour interval in (d) is 0.2 .

stronger troughs over the northwestern United States. Unlike the SGP, the regression of $250-\mathrm{mb}$ zonal wind anomalies on the NGP EGH index yields no significant features (not shown). However, regressions with the 250 -mb $v$-wind anomalies (Fig. 6c) depicts a negative to positive couplet over the northwestern United States, a key feature of NGP Pattern pluvial years in which the troughs over the northwestern United States induce a southerly flow to the east and a northerly flow to the west of the trough. These wind anomalies indicate that height anomalies over the northwestern United States alter the flow pattern during NGP Pattern pluvial years, again agreeing with the results of Flanagan et al. (2018) about the importance of the intensity of northwestern U.S. synoptic waves. The precipitation anomalies connected with the NGP EGH index show the 
opposite to that seen for the SGP EGH index precipitation regression. Positive anomalies are analyzed across the northern United States with negative anomalies across the southern North America as well as across the northern Pacific Ocean. These anomalies continue to show the enhanced trough over the northwestern United States, but lack information into other features that can be connected to the enhanced troughing.

\section{Discussion}

The diagnosis of the key circulation anomalies that define GP Pattern pluvial years is completed using composite analysis of various atmospheric and surface fields from the ERA-20C dataset. In the SGP, Pattern pluvial years are characterized by significant SST anomalies in the tropical Pacific (Figs. 2a, 3, and 5a). However, while previous work showed links between eastern tropical Pacific SST anomalies (canonical ENSO signal) and precipitation variability in the GP (Ting and Wang 1997; Yang et al. 2007; Hu and Huang 2009; Findell and Delworth 2010; Hunt 2011; Cook et al. 2011), our results suggest a link between the anomalous circulation pattern driving GP excessive precipitation and central tropical Pacific SST anomalies.

Streamfunction anomalies (Fig. 3) detail an "atmospheric bridge" (Lau 1997; Alexander et al. 2002) that connects the warm SST anomalies to North Pacific climate anomalies, including a southward shift in the jet stream and the subsequent enhancement of the frequency of synoptic waves during SGP Pattern pluvial years. However, the atmospheric response to a warm ENSO event is a stationary wave pattern that is directed to the east as it goes higher in latitude, whereas the response seen during Pattern pluvial years is located directly north of the main anomaly center analyzed in the SST composites. This atmospheric response is typically associated with CP warm SST periods (Livezey et al. 1997; Ashok et al. 2007; Fu et al. 2013).

The magnitude and structure of the streamfunction anomalies in our results compare well with previous works on CP ENSO teleconnections with NH atmospheric regimes (e.g., Livezey et al. 1997; Ashok et al. 2007; Graf and Zanchettin 2012; Fu et al. 2013). Indeed, SGP Pattern pluvial year streamfunction anomalies and those streamfunction anomalies linearly related to variability in the Niño-4 index (a proxy for central tropical Pacific SST anomalies) are markedly similar to one another (Fig. 7; spatial correlation of the two patterns is $r=$ 0.96). In addition, the correlation between the SGP EGH index and the Niño-4 is 0.626, further showing the connection between the CP SST variability and the

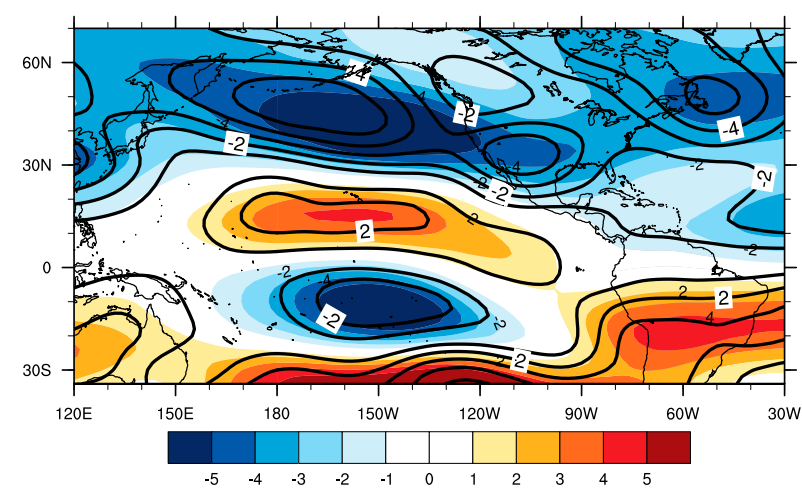

FIG. 7. 250-mb streamfunction contours for SGP Pattern pluvial years and color shading for the linear regression of the global streamfunction field onto the Niño-4 index. Contours and color shading was plotted between -5 and 5 every $1 \mathrm{~m}^{2} \mathrm{~s}^{-1} \times 10^{-6}$.

anomalous atmospheric signal during SGP Pattern pluvial years. Further, the response in the atmosphere to the CP SST anomalies is a ridge to the north of the tropical Pacific and a trough over the North Pacific as noted in our SGP Pattern pluvial results. These anomalous atmospheric height patterns cause an anomalous shift of the Pacific jet stream to the south. This shift in the jet stream shifts synoptic wave activity toward the southern United States, as the jet stream acts as the primary guide for synoptic waves across the Pacific Ocean basin (Branstator and Teng 2017). Hence, our results suggest a link between the atmospheric anomalies seen in the SGP Pattern pluvial analyses and the SST anomalies seen in the central tropical Pacific during SGP Pattern pluvial years. This is further seen in the season plots of SST anomalies during SGP Pattern pluvial years (Fig. 3). SST anomalies during DJF and MAM show a stronger signal in the $\mathrm{CP}$ than in the eastern portions of the tropical Pacific; in fact, during DJF the magnitude of the SST anomalies in the eastern Pacific is almost lower than the El Niño classification threshold $\left(0.5^{\circ} \mathrm{C}\right)$. These features are important owing to the larger impact of tropical Pacific SST anomalies on synoptic-scale systems during winter and spring compared to the rest of the year, owing to the seasonal nature of tropical Pacific SST anomaly development (e.g., Rasmusson and Carpenter 1982; Larkin and Harrison 2002; Stein et al. 2014). This is a marked difference compared to previous literature, which focused on the connections between North American climate, including specifically the central United States, and canonical ENSO events (e.g., Ting and Wang 1997; Seager et al. 2003; Schubert et al. 2004; Seager et al. 2005a,b; Mei and Wang 2011; Seager et al. 2014; Fernando et al. 2016; Pu et al. 2016). While the atmospheric response to the SST anomalies during SGP Pattern pluvial years is similar to that which occurs 
during a canonical El Niño event, the westward shift of the relevant streamfunction anomalies over the North Pacific and North America highlights clear differences between the atmospheric response of a canonical El Niño and a CP warm event.

The overall importance between CP SST anomalies and the circulation anomalies connected to SGP Pattern pluvial years is the increasing influence of SST anomalies in the CP in recent decades (e.g., Yeh et al. 2009; Wang et al. 2015; Freund et al. 2019). This is caused by the increased frequency of CP warm SST anomaly events compared to canonical ENSO events (Ashok et al. 2007; Yeh et al. 2009; Lee and McPhaden 2010) and the theorized links between CP warm SST events and anthropogenic climate change (Yeh et al. 2009; Freund et al. 2019). Thus, our results provide a further impact of the increased frequency of CP warm SST events, the possible increased frequency of the circulation anomaly that defines SGP Pattern pluvial years. However, further investigation is required to determine the robustness of this signal and to illuminate any links between more frequent CP warm SST events and more frequent SGP Pattern pluvial years.

During NGP Pattern pluvial years, no conclusive SST anomaly signal emerges in the analyses that can be directly linked to the occurrence of the key circulation anomalies linked to NGP Pattern pluvial years. The NGP SST Pattern composites (Fig. 4) and the regression coefficient plot (Fig. 6a) both showed positive signals over the north central Pacific, the KOE region, and the eastern-tropical Pacific, while the above average synoptic wave intensity Pattern pluvial years composite showed negative anomalies over the KOE region with more significant warm anomalies over the tropical $\mathrm{Pa}-$ cific. The seasonally persistent tropical Atlantic SST signal is the unique feature seen coincident with the circulation anomaly signal that defines NGP Pattern pluvial years. SST anomalies in the Caribbean and Gulf of Mexico contribute positively to moisture transport into the central United States via an amplified LLJ (e.g., Wang 2007; Wang and Lee 2007; Martin and Schumacher 2011). However, connections between Atlantic SSTs and NGP Pattern pluvial years are complex considering the positive north tropical Atlantic SST anomalies. Kushnir et al. (2010) found that north tropical Atlantic positive SST anomalies reduce the strength of the North Atlantic subtropical high and thus weaken moisture flow into the United States. Further, previous research has shown that warm north tropical Atlantic SST anomalies are connected to reduced precipitation over North America, including the GP (Enfield et al. 2001; Hoerling and Kumar 2003; Ruiz-Barradas and Nigam 2005; Seager et al. 2005a; Sutton and Hodson
2005; Schubert et al. 2009; Kushnir et al. 2010; Seager et al. 2014). Thus, our analysis shows that SST anomalies play little role in forcing the circulation anomalies that define NGP Pattern pluvial years. However as the SST anomalies in the Atlantic detailed above appear in our NGP Pattern pluvial year analyses, it is likely that they are playing a role in forcing these pluvial years. While this does point toward future work, investigating these features is outside the scope of this study.

Streamfunction anomalies during NGP Pattern pluvial years point toward the importance of the KOE region SST anomalies during these years. The annual NGP streamfunction anomaly Pattern composite (Fig. 4a) features only significant anomalies in the northwestern United States owing to the strong height anomalies that define the NGP pluvial pattern. A positive streamfunction anomaly (Fig. 6b) is seen over the North Pacific with a negative signal over the northwestern United States. These features link well with the north central Pacific SST anomalies seen in the Pattern composite and regression plot. SST anomalies in the KOE region are known to anchor the Pacific jet stream farther north and thus maintain a consistent synoptic wave signal over the region (Kwon et al. 2010; Ma et al. 2015, 2017). Thus, the SST anomalies could induce increased latent heat release, which would drive positive height anomalies across the KOE region and force the jet stream northward, maintaining a Pacific jet that is located in the northern latitudes.

\section{Summary and conclusions}

The overall goal of this work was to 1) diagnose the atmospheric signals found in Flanagan et al. (2018), 2) investigate the critical atmospheric and oceanic features seen during Pattern pluvial years, and 3) determine whether a robust, predictive SST signature existed for both the SGP and NGP Pattern pluvial years. Through our analysis, we found the following:

- The frequency of synoptic waves over the southwestern United States is a defining feature for SGP Pattern pluvial years.

- Streamfunction composites during SGP Pattern pluvial years revealed that an anomalous stationary wave feature over the central and North Pacific Ocean basin explains the shift in the Pacific jet stream, which subsequently increases the frequency of synoptic waves in the southwestern United States during these years.

- Warm SST anomalies over the tropical Pacific Ocean were found during SGP Pattern pluvial years, showing a link between central tropical Pacific warm SST anomalies and the anomalous circulation signal that defines SGP Pattern pluvial years. 


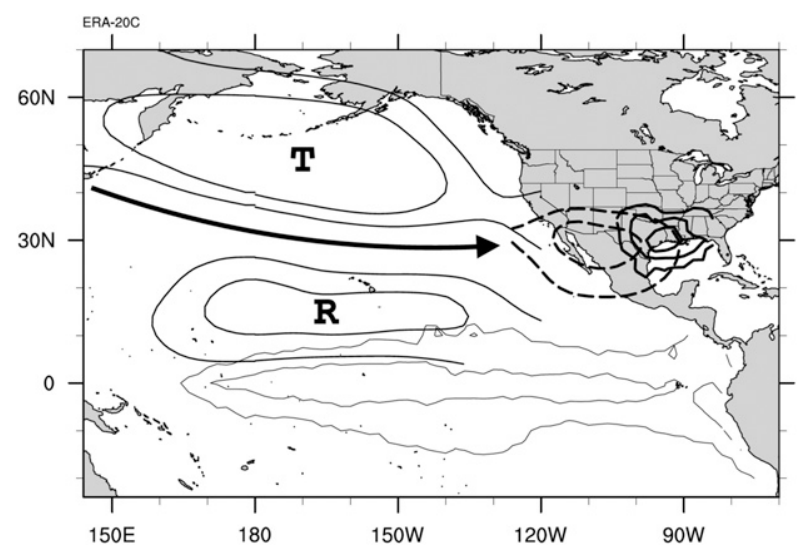

FIG. 8. Conceptual diagram of the SGP Pattern pluvial year paradigm. The light solid lines represent positive SST anomalies, the thick solid lines represent 250 -mb streamfunction anomalies, the dashed bold lines represent 500-mb EGH anomalies, and the solid bold lines represent the precipitation anomalies. The arrow represents the theorized jet stream resultant from the streamfunction anomalies, the "T" stands for trough (negative streamfunction anomalies), and the "R" stands for ridge (positive streamfunction anomalies). All contours were created using ERA20C anomaly fields.

- Statistical analysis showed that the frequency of synoptic waves over the northwestern United States could be crucial for the occurrence of NGP Pattern pluvial years, counter to results from Flanagan et al. (2018).

- SST anomalies during NGP Pattern pluvial years suggest a link between KOE region positive SST anomalies and the key circulation anomaly that defines NGP Pattern pluvial years.

- Atlantic SST anomalies during NGP Pattern pluvial years suggest a link between North Atlantic and tropical Atlantic SST anomalies and NGP Pattern pluvial years.

In the SGP, the Flanagan et al. (2018) atmospheric pattern associated with Pattern pluvial years shows a distinct SST and teleconnection signal connected to the central tropical Pacific. Thus, putting together the results from Flanagan et al. (2018) and this study one can describe a pathway from CP SST anomalies to the excessive precipitation over the SGP, a schematic of which is shown in Fig. 8. Our results show that the important features of pluvial years in the SGP driven by anomalous synoptic conditions are the increased frequency and intensity of synoptic waves over the southwestern United States in association with the location of the significant central tropical Pacific SST anomalies.

For the NGP it is difficult to synthesize the results into single paradigm given the results differ significantly for each different analysis method. The inconsistent results within the NGP Pattern pluvial year analysis show the lack of a link between Pattern pluvial years and largescale signals. Given the seasonality of precipitation during Pattern pluvial years in the NGP, the excessive precipitation in this region may be more linked to anomalous convective events than large-scale lowfrequency climate modes. Thus, further investigation into NGP pluvial years on shorter time scales using reanalysis datasets with spatial resolutions in which convection is better resolved would aid in diagnosing NGP pluvial years. This would also help in reaching more conclusive results in terms of the influence of KOE region SST anomalies on the key circulation anomalies during NGP Pattern pluvial years and the role of Atlantic SST anomalies during these pluvial years.

Finally, the atmospheric signals (i.e., the EGH and streamfunction anomaly signals) for NGP and SGP Pattern pluvial years found in Flanagan et al. (2018) and this study can now be diagnosed within different datasets, namely global climate model simulations. Analysis of model simulations under present climate conditions can be used to validate the results reported here and in Flanagan et al. (2018). Furthermore, using simulations of future climate change, we can determine the possible effects of climate variability and change on GP pluvial years and GP precipitation variability. Additionally, our work can be used for operational forecasting including an analysis of hindcast model simulations. Last, although the focus of this work is on longer time scales, our work can be adapted to investigate subseasonal to seasonal GP pluvial periods. Being able to accurately simulate and forecast pluvial events in the GP would greatly improve our use of available water resources and provide information to be able to better plan for future water scenarios.

Acknowledgments. This work was supported, in part, by the Agriculture and Food Research Initiative Competitive Grant (2013-69002) from the USDA National Institute of Food and Agriculture, the National Science Foundation Grant Award ICER1663840, and a cooperative agreement with the USDA Southern Plains Climate Hub. ERA-20C data shown in this manuscript are available from http://www.ecmwf.int. We would also like to thank the anonymous reviewers for their constructive comments on helping edit this manuscript to its current form.

\section{REFERENCES}

Alexander, M. A., I. Bladé, M. Newman, J. R. Lanzante, N.-C. Lau, and J. D. Scott, 2002: The atmospheric bridge: The influence of ENSO teleconnections on air-sea interaction over the global oceans. J. Climate, 15, 2205-2231, https://doi.org/10.1175/15200442(2002)015<2205:TABTIO>2.0.CO;2. 
Ashok, K., S. K. Behera, S. A. Rao, H. Weng, and T. Yamagata, 2007: El Niño Modoki and its possible teleconnection. J. Geophys. Res., 112, C11007, https://doi.org/10.1029/2006JC003798.

Barsugli, J. J., and P. D. Sardeshmukh, 2002: Global atmospheric sensitivity to tropical SST anomalies throughout the IndoPacific basin. J. Climate, 15, 3427-3442, https://doi.org/ 10.1175/1520-0442(2002)015<3427:GASTTS >2.0.CO;2.

Bates, G. T., M. P. Hoerling, and A. Kumar, 2001: Central U.S. springtime precipitation extremes: Teleconnections and relationships with sea surface temperature. J. Climate, 14, 3751-3766, https://doi.org/10.1175/1520-0442(2001)014<3751: CUSSPE $>2.0 . \mathrm{CO} ; 2$.

Berg, L., L. Riihimaki, Y. Qian, H. Yan, and M. Huang, 2015: The low-level jet over the Southern Great Plains determined from observations and reanalyses and its impact on moisture transport. J. Climate, 28, 6682-6706, https://doi.org/10.1175/ JCLI-D-14-00719.1.

Branstator, G., and H. Teng, 2017: Tropospheric waveguide teleconnections and their seasonality. J. Atmos. Sci., 74, 15131532, https://doi.org/10.1175/JAS-D-16-0305.1.

Chen, T.-C., 2002: A North Pacific short-wave train during the extreme phases of ENSO. J. Climate, 15, 2359-2376, https://doi.org/ 10.1175/1520-0442(2002)015<2359:ANPSWT>2.0.CO;2.

Chen, Z., Z. Wen, R. Wu, P. Zhao, and J. Cao, 2014: Influence of two types of El Niños on the East Asian climate during boreal summer: A numerical study. Climate Dyn., 43, 469-481, https://doi.org/10.1007/s00382-013-1943-1.

Chiodi, A. M., and D. E. Harrison, 2013: Impacts on seasonal U.S. atmospheric circulation, temperature, and precipitation anomalies: The OLR-event perspective. J. Climate, 26, 822837, https://doi.org/10.1175/JCLI-D-12-00097.1.

Christian, J., K. Christian, and J. B. Basara, 2015: Drought and pluvial dipole events within the Great Plains of the United States. J. Appl. Meteor. Climatol., 54, 1886-1898, https:// doi.org/10.1175/JAMC-D-15-0002.1.

Ciancarelli, B., C. L. Castro, C. Woodhouse, F. Dominguez, H.-I. Chang, C. Carrillo, and D. Griffin, 2014: Dominant patterns of US warm season precipitation variability in a fine resolution observational record, with focus on the Southwest. Int. J. Climatol., 34, 687-707, https://doi.org/10.1002/joc.3716.

Cook, B. I., R. Seager, and R. L. Miller, 2011: On the causes and dynamics of the early twentieth-century North American pluvial. J. Climate, 24, 5043-5060, https://doi.org/10.1175/ 2011JCLI4201.1.

Dai, A., and T. M. L. Wigley, 2000: Global patterns of ENSOinduced precipitation. Geophys. Res. Lett., 27, 1283-1286, https://doi.org/10.1029/1999GL011140.

Daly, C., G. H. Taylor, W. P. Gibson, T. W. Parzybok, G. L. Johnson, and P. A. Pasteris, 2000: High-quality spatial climate data sets for the United States and beyond. Trans. Amer. Soc. Agric. Eng., 43, 1957-1962, https://doi.org/10.13031/ 2013.3101.

Deser, C., and J. M. Wallace, 1990: Large-scale atmospheric circulation features of warm and cold episodes in the tropical Pacific. J. Climate, 3, 1254-1281, https://doi.org/10.1175/15200442(1990)003<1254:LSACFO>2.0.CO;2.

Ding, Q., and B. Wang, 2005: Circumglobal teleconnection in the Northern Hemisphere summer. J. Climate, 18, 3483-3505, https://doi.org/10.1175/JCLI3473.1.

, _ , J. M. Wallace, and G. Branstator, 2011: Tropicalextratropical teleconnections in boreal summer: Observed interannual variability. J. Climate, 24, 1878-1896, https:// doi.org/10.1175/2011JCLI3621.1.
Duchon, C. E., 1979: Lanczos filtering in one and two dimensions. J. Appl. Meteor., 18, 1016-1022, https://doi.org/10.1175/15200450(1979)018<1016:LFIOAT > 2.0.CO;2.

Enfield, D. B., A. M. Mestas-Nuñez, and P. J. Trimble, 2001: The Atlantic multidecadal oscillation and its relation to rainfall and river flows in the continental U.S. Geophys. Res. Lett., 28, 2077-2080, https://doi.org/10.1029/2000GL012745.

Fang, X.-H., and M. Mu, 2018: A three-region conceptual model for central Pacific El Niño including zonal advective feedback. J. Climate, 31, 4965-4979, https://doi.org/10.1175/ JCLI-D-17-0633.1.

Fernando, D. N., and Coauthors, 2016: What caused the spring intensification and winter demise of the 2011 drought over Texas? Climate Dyn., 47, 3077-3090, https://doi.org/10.1007/ s00382-016-3014-x.

Findell, K. L., and T. L. Delworth, 2010: Impact of common sea surface temperature anomalies on global drought and pluvial frequency. J. Climate, 23, 485-503, https://doi.org/10.1175/ 2009JCLI3153.1.

Flanagan, P. X., J. B. Basara, J. C. Furtado, and X. Xiao, 2018: Primary atmospheric drivers of pluvial years in the United States Great Plains. J. Hydrometeor., 19, 643-658, https:// doi.org/10.1175/JHM-D-17-0148.1.

Frankignoul, C., and N. Sennéchael, 2007: Observed influence of North Pacific SST anomalies on the atmospheric circulation. J. Climate, 20, 592-606, https://doi.org/10.1175/JCLI4021.1.

Freund, M. B., B. J. Henley, D. J. Karoly, H. V. McGregor, N. J. Abram, and D. Dommenget, 2019: Higher frequency of Central Pacific El Niño events in recent decades relative to past centuries. Nat. Geosci., 12, 450-455, https://doi.org/ 10.1038/S41561-019-0353-3.

Fu, J., M. Zhang, Z. Han, and S. Li, 2013: Sensitivity difference in the extratropical atmosphere to two types of El Niño events. Atmos. Oceanic Sci. Lett., 6, 355-359, https://doi.org/10.3878/ j.issn.1674-2834.13.0004.

Garfinkel, C. I., M. M. Hurwitz, D. W. Waugh, and A. H. Butler, 2013: Are the teleconnections of central Pacific and eastern Pacific El Niño distinct in boreal wintertime? Climate Dyn., 41, 1835-1852, https://doi.org/10.1007/s00382-012-1570-2.

Gershunov, A., and T. Barnett, 1998: ENSO influence on intraseasonal extreme rainfall and temperature frequencies in the contiguous United States: Observations and model results. J. Climate, 11, 1575-1586, https://doi.org/10.1175/ 1520-0442(1998)011<1575:EIOIER > 2.0.CO;2.

Graf, H.-F., and D. Zanchettin, 2012: Central Pacific El Niño, the "subtropical bridge," and Eurasian climate. J. Geophys. Res., 117, D01102, https://doi.org/10.1029/2011JD016493.

Guo, Y.-Y., M. Ting, Z. Wen, and D. E. Lee, 2017: Distinct patterns of tropical Pacific SST anomaly and their impacts on North American climate. J. Climate, 30, 5221-5241, https://doi.org/ 10.1175/JCLI-D-16-0488.1.

Harrison, D. E., and N. K. Larkin, 1998: El Niño-Southern Oscillation sea surface temperature and wind anomalies, 19461993. Rev. Geophys., 36, 353-400, https://doi.org/10.1029/ 98RG00715.

Helfand, H. M., and S. D. Schubert, 1995: Climatology of the simulated Great Plains low-level jet and its contribution to the continental moisture budget of the United States. J. Climate, $\mathbf{8}$, 784-806, https://doi.org/10.1175/1520-0442(1995)008<0784: COTSGP $>2.0 . \mathrm{CO} ; 2$.

Higgins, R. W., Y. Yao, E. S. Yarosh, J. E. Janowiak, and K. C. Mo, 1997: Influence of the Great Plains low-level jet on summertime precipitation and moisture transport over the central 
United States. J. Climate, 10, 481-507, https://doi.org/10.1175/ 1520-0442(1997)010<0481:IOTGPL > 2.0.CO;2.

Hoerling, M. P., and A. Kumar, 2003: The perfect ocean for drought. Science, 299, 691-694, https://doi.org/10.1126/science. 1079053.

—_ — - and M. Zhong, 1997: El Niño, La Niña, and the nonlinearity of their teleconnections. J. Climate, 10, 17691786, https://doi.org/10.1175/1520-0442(1997)010<1769: ENOLNA $>2.0 . \mathrm{CO} ; 2$.

$\mathrm{Hu}, \mathrm{Q}$., and S. Feng, 2001: Variations of teleconnections of ENSO and interannual variations in summer rainfall in the central United States. J. Climate, 14, 2469-2480, https://doi.org/ 10.1175/1520-0442(2001)014<2469:VOTOEA > 2.0.CO;2.

$\mathrm{Hu}, \mathrm{Z}$., and B. Huang, 2009: Interferential impact of ENSO and PDO on dry and wet conditions in the U.S. Great Plains. J. Climate, 22, 6047-6065, https://doi.org/10.1175/ 2009JCLI2798.1.

Hunt, B. G., 2011: Global characteristics of pluvial and dry multiyear episodes, with emphasis on megadroughts. Int. J. Climatol., 31, 1425-1439, https://doi.org/10.1002/joc.2166.

Kao, H.-Y., and J.-Y. Yu, 2009: Contrasting eastern-Pacific and central-Pacific types of ENSO. J. Climate, 22, 615-632, https:// doi.org/10.1175/2008JCLI2309.1.

Knippertz, P., and H. Wernli, 2010: A Lagrangian climatology of tropical moisture exports to the Northern Hemisphere extratropics. J. Climate, 23, 987-1003, https://doi.org/10.1175/ 2009JCLI3333.1.

Kug, J.-S., F.-F. Jin, and S.-I. An, 2009: Two types of El Niño events: Cold tongue El Niño and warm pool El Niño. J. Climate, 22, 1499-1515, https://doi.org/10.1175/2008JCLI2624.1.

Kuo, Y. H., M. A. Shapiro, and E. G. Donall, 1991: The interaction between baroclinic and diabatic processes in a numerical simulation of a rapidly intensifying extratropical marine cyclone. Mon. Wea. Rev., 119, 368-384, https://doi.org/10.1175/ 1520-0493(1991)119<0368:TIBBAD > 2.0.CO;2.

Kushnir, Y., R. Seager, M. Ting, N. Naik, and J. Nakamura, 2010: Mechanisms of tropical Atlantic SST influence on North American precipitation variability. J. Climate, 23, 5610-5628, https://doi.org/10.1175/2010JCLI3172.1.

Kwon, Y.-O., M. A. Alexander, N. A. Bond, C. Frankignoul, H. Nakamura, B. Qiu, and L. Thompson, 2010: Role of the Gulf Stream and Kuroshio-Oyashio systems in large-scale atmosphere-ocean interaction: A review. J. Climate, 23, 32493281, https://doi.org/10.1175/2010JCLI3343.1.

Larkin, N. K., and D. E. Harrison, 2002: ENSO warm (El Niño) and cold (La Niña) event life cycles: Ocean surface anomaly patterns, their symmetries, asymmetries, and implications. J. Climate, 15, 1118-1140, https://doi.org/10.1175/ 1520-0442(2002)015<1118:EWENOA>2.0.CO;2.

— seasonal average U.S. weather anomalies. Geophys. Res. Lett., 32, L13705, https://doi.org/10.1029/2005GL022738.

$\longrightarrow$, and _ 2005b: Global seasonal temperature and precipitation anomalies during El Niño autumn and winter. Geophys. Res. Lett., 32, L16705, https://doi.org/10.1029/2005GL022860.

Lau, K.-M., and H.-Y. Weng, 2002: Recurrent teleconnection patterns linking summertime precipitation variability over East Asia and North America. J. Meteor. Soc. Japan, 80, 13091324, https://doi.org/10.2151/jmsj.80.1309.

, J.-Y. Lee, K.-M. Kim, and I.-S. Kang, 2004: The North Pacific as a regulator of summertime climate over Eurasia and North America. J. Climate, 17, 819-833, https://doi.org/10.1175/15200442(2004)017<0819:TNPAAR >2.0.CO;2.
Lau, N.-C., 1997: Interactions between global SST anomalies and the midlatitude atmospheric circulation. Bull. Amer. Meteor. Soc., 78, 21-33, https://doi.org/10.1175/1520-0477(1997)078<0021: IBGSAA $>2.0 . \mathrm{CO} ; 2$.

Lee, T., and M. J. McPhaden, 2010: Increasing intensity of El Niño in the central-equatorial Pacific. Geophys. Res. Lett., 37, L14603, https://doi.org/10.1029/2010GL044007.

L'Heureux, M. L., M. K. Tippett, and A. G. Barnston, 2015: Characterizing ENSO coupled variability and its impact on North American seasonal precipitation and temperature. J. Climate, 28, 4231-4245, https://doi.org/10.1175/JCLI-D-14-00508.1.

Livezey, R. E., M. Masutani, A. Leetmaa, H. Rui, M. Ji, and A. Kumar, 1997: Teleconnective response of the Pacific-North American region atmosphere to large central equatorial $\mathrm{Pa}-$ cific SST anomalies. J. Climate, 10, 1787-1820, https://doi.org/ 10.1175/1520-0442(1997)010<1787:TROTPN >2.0.CO;2.

Ma, X., and Coauthors, 2015: Distant influence of Kuroshio eddies on North Pacific weather patterns? Sci. Rep., 5, 17785, https:// doi.org/10.1038/srep17785.

_, P. Chang, R. Saravanan, R. Montuoro, H. Nakamura, D. Wu, X. Lin, and L. Wu, 2017: Importance of resolving Kuroshio front and eddy influence in simulating the North Pacific storm track. J. Climate, 30, 1861-1880, https://doi.org/10.1175/JCLID-16-0154.1.

Mantua, N. J., and S. R. Hare, 2002: The Pacific decadal oscillation. J. Oceanogr., 58, 35-44, https://doi.org/10.1023/A: 1015820616384.

, Y. Zhang, J. M. Wallace, and R. C. Francis, 1997: A Pacific interdecadal climate oscillation with impacts on salmon production. Bull. Amer. Meteor. Soc., 78, 1069-1079, https://doi.org/ 10.1175/1520-0477(1997)078<1069:APICOW>2.0.CO;2.

Martin, E. R., and C. Schumacher, 2011: The Caribbean low-level jet and its relationship with precipitation in IPCC AR4 models. J. Climate, 24, 5935-5950, https://doi.org/10.1175/ JCLI-D-11-00134.1.

Mei, R., and G. Wang, 2011: Impact of sea surface temperature and soil moisture on summer precipitation in the United States based on observational data. J. Hydrometeor., 12, 1086-1099, https://doi.org/10.1175/2011JHM1312.1.

Mills, C., and J. E. Walsh, 2013: Seasonal variation and spatial patterns of the atmospheric component of the Pacific decadal oscillation. J. Climate, 26, 1575-1594, https://doi.org/10.1175/ JCLI-D-12-00264.1.

Nakamura, H., T. Sampe, Y. Tanimoto, and A. Shimpo, 2004: Observed associations among storm tracks, jet streams and midlatitude oceanic fronts. Earth's Climate: The OceanAtmosphere Interaction, Geophys. Monogr., Vol. 147, Amer. Geophys. Union, 329-346.

Neelin, J. D., 2011: Climate Change and Climate Modeling. Cambridge University Press, 304 pp.

Newman, M., G. Compo, and M. Alexander, 2003: ENSO-forced variability of the Pacific decadal oscillation. J. Climate, 16, 3853-3857, https://doi.org/10.1175/1520-0442(2003)016<3853: EVOTPD $>2.0 . \mathrm{CO} ; 2$.

_ , and Coauthors, 2016: The Pacific decadal oscillation, revisited. J. Climate, 29, 4399-4427, https://doi.org/10.1175/ JCLI-D-15-0508.1.

Nigam, S., B. Guan, and A. Ruiz-Barradas, 2011: Key role of the Atlantic multidecadal oscillation in 20th century drought and wet periods over the Great Plains. Geophys. Res. Lett., 38, L16713, https://doi.org/10.1029/2011GL048650.

Oglesby, R. J., K. A. Maasch, and B. Saltzman, 1989: Glacial meltwater cooling of the Gulf of Mexico: GCM implications 
for Holocene and present-day climate. Climate Dyn., 3, 115133, https://doi.org/10.1007/BF01080364.

Poli, P., and Coauthors, 2016: ERA-20C: An atmospheric reanalysis of the twentieth century. J. Climate, 29, 4083-4097, https://doi.org/10.1175/JCLI-D-15-0556.1.

Pu, B., R. Fu, R. E. Dickinson, and D. N. Fernando, 2016: Why do summer droughts in the southern Great Plains occur in some La Niña years but not others? J. Geophys. Res. Atmos., 121, 1120-1137, https://doi.org/10.1002/2015JD023508.

Rasmusson, E. M., and T. H. Carpenter, 1982: Variation in tropical sea surface temperature and surface wind fields associated with the Southern Oscillation/El Niño. Mon. Wea. Rev., 110, 354-384, https://doi.org/10.1175/1520-0493(1982)110<0354: VITSST $>2.0 . \mathrm{CO} ; 2$

Rayner, N. A., D. E. Parker, E. B. Horton, C. K. Folland, L. V. Alexander, D. P. Rowell, E. C. Kent, and A. Kaplan, 2003: Global analyses of sea surface temperature, sea ice, and night marine air temperature since the late nineteenth century. J. Geophys. Res. 108, 4407, https://doi.org/10.1029/2002JD002670.

Reed, R. J., G. A. Grell, and Y. H. Kuo, 1993: The ERICA IOP 5 Storm. Part II: Sensitivity tests and further diagnosis based on model output. Mon. Wea. Rev., 121, 1595-1612, https://doi.org/ 10.1175/1520-0493(1993)121<1595:TEISPI > 2.0.CO;2.

Ropelewski, C. F., and M. S. Halpert, 1986: North American precipitation and temperature patterns associated with the $\mathrm{E}$ Niño/Southern Oscillation (ENSO). Mon. Wea. Rev., 114, 2352-2362, https://doi.org/10.1175/1520-0493(1986)114<2352. NAPATP $>2.0 . C O ; 2$.

— terns associated with the El Niño/Southern Oscillation. Mon. Wea. Rev., 115, 1606-1626, https://doi.org/10.1175/ 1520-0493(1987)115<1606:GARSPP > 2.0.CO;2.

_ , and 1989: Precipitation patterns associated with the high index phase of the Southern Oscillation. J. Climate, 2 , 268-284, https://doi.org/10.1175/1520-0442(1989)002<0268: PPAWTH $>2.0 . \mathrm{CO} ; 2$.

Ruiz-Barradas, A., and S. Nigam, 2005: Warm-season rainfall variability over the U.S. Great Plains in observations, NCEP and ERA-40 reanalyses, and NCAR and NASA atmospheric model simulations. J. Climate, 18, 1808-1830, https://doi.org/ 10.1175/JCLI3343.1.

Sanders, F., 1986: Explosive cyclogenesis over the west-central North Atlantic Ocean, 1981-84. Part I: Composite structure and mean behavior. Mon. Wea. Rev., 114, 1781-1794, https://doi.org/ 10.1175/1520-0493(1986)114<1781:ECITWC>2.0.CO;2.

Schneider, N., and B. D. Cornuelle, 2005: The forcing of the Pacific decadal oscillation. J. Climate, 18, 4355-4373, https://doi.org/ 10.1175/JCLI3527.1.

Schubert, S. D., M. J. Suarez, P. J. Pegion, R. D. Koster, and J. T. Bacmeister, 2004: On the cause of the 1930s Dust Bowl. Science, 303, 1855-1859, https://doi.org/10.1126/science.1095048.

$\leftarrow,-,-,-$, and,- 2008 : Potential predictability of long-term drought and pluvial conditions in the U.S. Great Plains. J. Climate, 21, 802-816, https://doi.org/10.1175/ 2007JCLI1741.1.

—- and Coauthors, 2009: A U.S. CLIVAR project to assess and compare the responses of global climate models to droughtrelated SST forcing patterns: Overview and results. J. Climate, 22, 5251-5272, https://doi.org/10.1175/2009JCLI3060.1.

- and Coauthors, 2016: Global meteorological drought: A synthesis of current understanding with a focus on SST drivers of precipitation deficits. J. Climate, 29, 3989-4019, https:// doi.org/10.1175/JCLI-D-15-0452.1.
Seager, R., and M. P. Hoerling, 2014: Atmosphere and ocean origins of North American drought. J. Climate, 27, 4581-4606, https://doi.org/10.1175/JCLI-D-13-00329.1.

—, N. Harnik, Y. Kushnir, W. Robinson, and J. Miller, 2003: Mechanisms of hemispherically symmetric climate variability. J. Climate, 16, 2960-2978, https://doi.org/10.1175/15200442(2003)016<2960:MOHSCV>2.0.CO;2.

Y. Kushnir, C. Herweijer, N. Naik, and J. Velez, 2005a: Modeling of tropical forcing of persistent droughts and pluvials over western North America: 1856-2000. J. Climate, 18, 4065-4088, https://doi.org/10.1175/JCLI3522.1.

—, N. Harnik, W. A. Robinson, Y. Kushnir, M. Ting, H. P. Huang, and J. Velez, 2005b: Mechanisms of ENSO-forcing of hemispherically symmetric precipitation variability. Quart. J. Roy. Meteor. Soc., 131, 1501-1527, https://doi.org/10.1256/ qj.04.96.

— , L. Goddard, J. Nakamura, N. Henderson, and D. E. Lee, 2014: Dynamical causes of the 2010/11 Texas-northern Mexico drought. J. Hydrometeor., 15, 39-68, https://doi.org/ 10.1175/JHM-D-13-024.1.

Stein, K., A. Timmermann, N. Schneider, F.-F. Jin, and M. F. Stuecker, 2014: ENSO seasonal synchronization theory. J. Climate, 27, 5285-5310, https://doi.org/10.1175/JCLI-D-13-00525.1.

Sutton, R. T., and D. L. R. Hodson, 2005: Atlantic Ocean forcing of North American and European summer climate. Science, 309, 115-118, https://doi.org/10.1126/science.1109496.

Ting, M., and H. Wang, 1997: Summertime U.S. precipitation variability and its relation to Pacific sea surface temperature. J. Climate, 10, 1853-1873, https://doi.org/10.1175/15200442(1997)010<1853:SUSPVA $>2.0$. CO;2.

Trenberth, K. E., 1997: The definition of El Niño. Bull. Amer. Meteor. Soc., 78, 2771-2777, https://doi.org/10.1175/15200477(1997)078<2771:TDOENO>2.0.CO;2.

- G. W. Branstator, D. Karoly, A. Kumar, N.-C. Lau, and C. Ropelewski, 1998: Progress during TOGA in understanding and modeling global teleconnections associated with tropical sea surface temperatures. J. Geophys. Res., 103, 14 291-14324, https://doi.org/10.1029/97JC01444.

Wallace, J. M., and P. V. Hobbs, 1977: Atmospheric Science: An Introductory Survey. Academic Press, $467 \mathrm{pp}$.

Wang, C., 2007: Variability of the Caribbean low-level jet and its relations to climate. Climate Dyn., 29, 411-422, https://doi.org/ 10.1007/s00382-007-0243-z.

— level jet, and their potential impact on Atlantic hurricanes. Geophys. Res. Lett., 34, L02703, https://doi.org/10.1029/ 2006GL028579.

Wang, F., Z. Liu, and M. Notaro, 2013: Extracting the dominant SST modes impacting North America's observed climate. J. Climate, 26, 5434-5452, https://doi.org/10.1175/JCLI-D-1200583.1.

Wang, H., S. Schubert, M. Suarez, and R. Koster, 2010: The physical mechanisms by which the leading patterns of SST variability impact U.S. precipitation. J. Climate, 23, 18151836, https://doi.org/10.1175/2009JCLI3188.1.

Wang, S.-Y., W.-R. Huang, H.-H. Hsu, and R. R. Gillies, 2015: Role of the strengthened El Niño teleconnection in the May 2015 floods over the southern Great Plains. Geophys. Res. Lett., 42, 8140-8146, https://doi.org/10.1002/2015GL065211.

Wirth, V., M. Riemer, E. Chang, and O. Martius, 2018: Rossby wave packets on the midlatitude waveguide-A review. Mon. Wea. Rev., 146, 1965-2001, https://doi.org/10.1175/MWR-d16-0483.1. 
Yang, S., X. Ding, D. Zheng, and Q. Li, 2007: Depiction of the variations of Great Plains precipitation and its relationship with tropical central-eastern Pacific SST. J. Appl. Meteor. Climatol., 46, 136-153, https://doi.org/10.1175/ JAM2455.1.

Yeh, S.-W., J.-S. Kug, B. Dewitte, M.-H. Kwon, B. Kirtman, and F.-F. Jin, 2009: El Niño in a changing climate. Nature, 461, 511-514, https://doi.org/10.1038/nature08316.
Yu, B., X. Zhang, H. Lin, and J.-Y. Yu, 2015: Comparison of wintertime North American climate impacts associated with multiple ENSO indices. Atmos.-Ocean, 53, 426-445, https:// doi.org/10.1080/07055900.2015.1079697.

Yu, J.-Y., and H.-Y. Kao, 2007: Decadal changes of ENSO persistence barrier in SST and ocean heat content indices: 19582001. J. Geophys. Res., 112, D13106, https://doi.org/10.1029/ 2006JD007654. 